\title{
BIOCHEMICAL PROPERTIES IN VASCULAR EPIPHYTES SUBSTRATE FROM A TEMPERATE FOREST OF CHILE
}

\author{
Francisco Reyes ${ }^{1,2}$, Silvana Zanetti ${ }^{3}$, Alejandro Espinosa ${ }^{4}$ and Marysol Alvear ${ }^{1,2^{*}}$ \\ ${ }^{1}$ Departamento de Ciencias Químicas; Facultad de Ingeniería, Ciencias y Administración and \\ ${ }^{2}$ Scientifical and Technological Bioresource Nucleus (BIOREN); Universidad de La Frontera, \\ Avenida Francisco Salazar 01145, Casilla 54-D, Temuco, Chile; ${ }^{3}$ Università degli studi di \\ Firenze, Firenze, Italia. ${ }^{4}$ Departamento de Ciencias Forestales, Facultad de Ciencias \\ Agropecuarias y Forestales, Universidad de La Frontera. \\ *Corresponding author: malvear@ufro.cl
}

\begin{abstract}
The temperate forests of south-central Chile belong to the association Lapageria aextoxiconetum Oberdorfer vegetation, dominated by Aextoxicon punctatum R. et P., elderly and multi-layered, where the strata are emergent, dominant and co-dominant, shrub and herbaceous epiphytes. This work is the first report of measurements of some biochemical properties in samples from vascular epiphytes substrate in temperate forests. We evaluated the most frequent ecological situations: bifurcated trees (BT), dead standing trees (SDT) and medium gap border trees (MGBT), ES were compared with the surrounding soil forest land (SS) as control. The microbial biomass and enzyme activities of substrate were higher in ES of BT, situation probably due to optimal micro-environmental conditions (moisture and humidity, temperature, organic matter (OM) content and nutrient availability); similarly, lower levels of activity were found in ES in MGBT situation. We found a statistically significant correlation ( $\mathrm{p} \leq$ 0.05 ) between evaluated microbial biomass and enzymatic activities. Furthermore, the biochemical properties were influenced by factors such as moisture, temperature, $\mathrm{pH}$ and $\mathrm{OM}$ content and all of these factors correlated significantly $(P \leq 0.01)$ among them. These results demonstrate a difference between ES and SS in BT that should be explored to gain insights in understanding the processes of decomposition using the natural microcosms that ES provides.
\end{abstract}

Keywords: vascular epiphytes substrate, enzymatic activities, temperate forest.

\section{INTRODUCTION}

Temperate rainforests of southern Chile have a global importance based on 2 outstanding aspects: the existence of continuous undisturbed forests which in other temperate regions of the world have practically disappeared and the extraordinary biodiversity of the region (Armesto et al., 1998, Olson et al.,
2001). According to Arroyo et al. (1996), the temperate rainforest in southern Chile is composed of 443 species of vascular plants with 160 woody species (44 species of trees corresponding to 32 genera and 20 families) and 283 herbaceous species. More than $70 \%$ of forest species in southern Chile are 
concentrated between $36^{\circ}$ and $40^{\circ} \mathrm{S}$ and correspond to the area of our country with greater biodiversity.

The precipitation chemistry in Chile still reflects a close approximation of preindustrial conditions (Godoy et al., 2001). In this way, the productivity of the ecosystem depends on the internal cycling of soil organic matter (SOM) (Vann et al., 2002, Perez et al., 2005).

In the temperate forests of Chile, mainly located in soils with restrictive characteristics of nitrogen and phosphorus, it is absolutely necessary to preserve the available nutrients and minimize the losses through gases or leaching (Huygens et al., 2008 ), in those areas with high rainfall, where the atmospheric $\mathrm{N}$ inputs are minimum. The main way to save nutrients in forests ecosystems in the southern hemisphere is through the presence and decay of organic matter deposited in the soil (Pérez et al., 2005, Schlegel and Donoso, 2008). Moreover, the OM improves the structure of the soil and its ability to retain humidity, which becomes a basic condition to the productive potential of the forest (Schllegel and Donoso, 2008).

In these forests, there are interrelationships among trees and other organisms, as well as between certain species of grass, shrubs and animals associated strata forming communities or "subcommunities", each of them with different demands on the physical and chemical environment, to which plants respond with adaptations as growth characteristics (Steubing et al., 2002), giving a structure and species composition in themselves (Kimmins, 1996). The epiphytism is an interspecific relationship that is part of commensalism (Smith and Smith, 2001), where one species benefits (the epiphyte is supported) and the other one is unaffected (Donoso, 1992). Granados and Tapia (1990), described plants that have no direct relationship with the soil and that develop on stems, branches and even leaves, as epiphytes, but they can also be developed on rocks hence, not directly soil to supply nutrients and water. On the other hand, HernándezRosas (2001) indicates that presence of epiphytes is influenced by climatic and biotic factors that are related to the substrate.

Epiphytes contribute to enhance the forest biodiversity (Antibus and Lesica, 1990; Hernández-Rosas, 2001). Moreover, Cardelús et al. (2006) showed that some species of epiphytes are useful as change indicators in several ecosystems, as well as providing fruit, nectar, water and other compounds into other organisms. Therefore, they are considered as an important component within the structure and dynamics of the forest, because they have ability to intercept nutrients within ecosystems.

Epiphytes have been studied in tropical forests (Vance and Nadkarni, 1990, Nadkarni et al., 2004; Higuera and Martínez, 2006). Colonization of vascular epiphytes on trees depends on the characteristics of the substrate, the exudation of compounds from the bark and/or deposit material from the decomposition of non-vascular epiphytes, including mosses and liverworts (Hernández-Rosas, 2001). This interaction would be capable of further proliferation, diversity and activity of microorganisms together with secretion of enzymes, due to a rich labile carbon and nitrogen compound, supply mainly used as energy sources.

Recently, Rousk and Nadskarni (2009) help understanding processes of decomposition in ecosystem forest and have investigated the relative importance of the two major decomposer groups (fungi and bacteria) in canopy and forest soils of a North American temperate wet forest. 
On the other hand, the organisms represented by a small fraction of soil $\mathrm{OM}$ are responsible for mineralization processes (Vance et al., 1987; Vance and Nadkarni 1990). Microbial biomass in soil is a catabolic agent of biogeochemical processes and energy and nutrient reservoir, but very susceptible to changes in land use and physicochemical characteristics of the environment. It determines the balance of ecosystem productivity (Galantini and Suñer, 2008). There are early biological indicators such as fluorescein diacetate (FDA) hydrolysis, which quantifies active microbial biomass (Alvear et al., 2008), the $\mathrm{C}$ and $\mathrm{N}$ biomass (MBC and MBN, respectively), whose determination shows the size of the microbial community present in substrates and soils (Alvear et al., 2007; Alvear et al., 2008). Moreover, Zagal et al. (2002) indicate that MBC and MBN constitute an essential measure of ecological importance, since one part represents the level of biological activity involving the labile component of OM and the other, integrating environmental factors and their influence on it. In addition, hydrolytic enzymes, such as acid phosphatase, involved in the cycle of phosphorus and the urease, involved in the nitrogen cycle, play a fundamental role in the cycling of nutrients for growth and for maintenance of vascular epiphytes in the forest ecosystems (Vance and Nadkarni, 1990; Hernández-Rosas, 2001; Nadkarni et al., 2004).

Measurement of biochemical parameters (Alvear et al., 2007) allow to analyze the interaction between the ES, in respect to the ecological function, especially the relationship between nutrients and habitat conditions.

This work is the first report of a temperate forest of Chile that considers measurements of some biochemical properties in ES in the three most common ecological situations (BT, DST and MGBT) compared with the surrounding soil. We hypothesize that the biochemical properties of vascular epiphytes substrate are affected by ecological conditions of the host trees.

\section{MATERIALS AND METHODS}

\section{Site characteristics}

The study was carried out in Rucamanque ( $\left.38^{\circ} 39^{\prime} \mathrm{S}, 72^{\circ} 35^{\prime} \mathrm{W}\right)$, Araucanía Region, Chile (Figure 1). It has an area of 435 ha, an average altitude of $376 \mathrm{~m}$, being $62 \%$ of its area between 201 and 400 masl. The climate is temperate and humid, with an average annual temperature and rainfall of $1,400 \mathrm{~mm}$ and $12^{\circ} \mathrm{C}$, respectively (Zúñiga et al., 2008).

The selected forest vegetation belongs to the Lapagerio Aextoxiconetum Oberdorfer association, dominated by Aextoxicon punctatum R. et P., the oldest and multi-layered, where there are emerging strata (mainly Nothofagus obliqua (Mirb) Oerst.) dominant and codominant (consisting of tolerant species and semitolerant as Aextoxicon punctatum, Persea lingue (R. et P.) Ness, Weinmannia trichosperma Cav. and Laureliopsis philippiana (Phil) Losser), shrub, and herbaceous epiphytes (San Martín et al., 2008).

\section{Sampling Design}

Within a $1,000 \mathrm{~m}^{2}$ plot of a addressed random was raised, 30 mature trees $(\mathrm{DHB} \geq 10 \mathrm{~cm})$ were sampled in order to identify the vascular epiphyte vegetation on the shafts of two forest species and to characterize the forest compositional variation, considering both the phorophytes species and the most frequent colonization situations. Three mature trees for the more frequent 


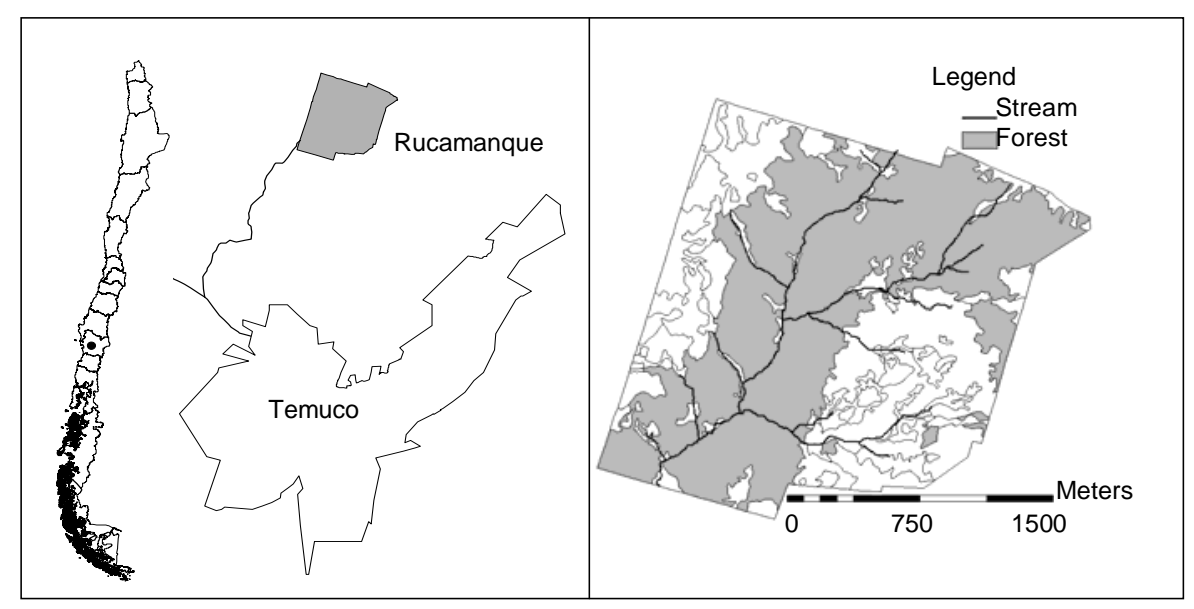

Figure 1. Study site location, vegetation belonging to the association Lapagerio aextoxiconetum Oberdorfer, south-central Chile ( $\left.38^{\circ} 39^{\prime} \mathrm{S}\right)$.

colonization situations were selected, from which epiphytes substrate (ES) samples and surrounding soil forest land (SS) were extracted. The most frequent situations for colonization taken into account were: a) bifurcated trees (BT), represented for $A$. punctatum species with organic matter accumulation; dead standing trees (DST), all of them belonging to $A$. punctatum; and medium gap border trees (MGBT) $\left(\leq 500 \mathrm{~m}^{2}\right)$ of $N$. obliqua species. Three ES and SS samples representing each most frequent situation for colonization were collected during 2006 autumn season. The SS samples were collected at $0-15 \mathrm{~cm}$ soil depth and ES sampling plots size were $250 \mathrm{~cm}^{2}$ and were located on the longitudinal axis of colonized shafts, with a distance between plots of $75 \mathrm{~cm}$. In BT ecological situation, the three plots were located next to each other along the tree bifurcation. The average distance between the samples for each situation was 20 meters, except for MGBT, where the average distance was 5 meters. ES samples were difficult to obtain and that's was the reason for not take over $50 \mathrm{~g}$ in each sample. Samples were moved to the laboratory in isothermal bags, sieved $(<2 \mathrm{~mm})$ and stored at $4^{\circ} \mathrm{C}$ for later analyses, which were performed within 20 days after sample collection.

Analytical results were made in triplicate and were calculated on the basis of oven-dried weight at standard temperature $\left(105^{\circ} \mathrm{C}\right)$.

\section{Assessment of vascular epiphyte vegetation}

Attributes of the vascular epiphytic flora were evaluated: species present in each settlement on the shaft (Hernández-Rosas, 2001), coverage through the projection on the shaft of each of the present vascular epiphyte species (Margalef, 1998; Hernández-Rosas, 2001) and sociability, which identifies the type of grouping that showed the species, indicated through simple observation.

\section{Determination of hydrolysis of FDA, MBC and MBN}

FDA hydrolysis was performed according to the method described by Alvear et al. 
(2008), expressing results as $\mu \mathrm{g}$ of fluorescein $\mathrm{g}^{-1}$. Microbial biomass $\mathrm{C}$ (MBC) and $\mathrm{N}(\mathrm{MBN})$ were determined according to the fumigation-extraction method (Vance et al., 1987). Carbon concentration of fumigated and nonfumigated samples was determined through oxidation with potassium dichromate and the difference was divided by the recovery factor $\mathrm{K}_{\mathrm{ec}}=0.45$ (Joergensen, 1996). Nitrogen concentration was calculated as the difference of reactive $\mathrm{N}$ to ninhydrin of fumigated and non-fumigated samples through the colorimetric method (Joergensen and Brookes, 1990). Biomass $\mathrm{N}$ values were calculated by using $\mathrm{K}_{\mathrm{en}}=0.54$ (Brookes et al., 1985). The results were expressed as $\mu \mathrm{g} \mathrm{C} \mathrm{g}^{-1}$ and $\mu \mathrm{g}$ $\mathrm{N} \mathrm{g}^{-1}$ for the $\mathrm{MBC}$ and NBM, respectively.

\section{Determination of enzyme activities}

Acid phosphatase activity (EC 3.1.6.1) was determined according to the method outlined by Alvear et al. (2008), and this activity was expressed as $\mu \mathrm{mol}$ PNP $\mathrm{g}^{-1}$ $\mathrm{h}^{-1}$. Urease activity (EC 3.5.1.5.) was determined using to the modified method of Alvear et al. (2008) and the data were expressed as $\mu$ moles $\mathrm{NH}_{3} \mathrm{~g}^{-1} \mathrm{~h}^{-1}$.

\section{Experimental design and statistical analyses}

An addressed random sampling was raised. Variables for biochemical properties and physical-chemical factors showed no normality assumption being transformed yet by natural logarithm function, so they were subjected to the nonparametric Kruskal-Wallis test to determine whether there were significant differences, with a significance level of 95\% $(P \leq 0.05)$. The level of correlation between biological activities was made by Pearson's test with a significance level of $99 \%(P \leq 0.01)$. For statistical analysis the demo version of SPSS 11.0 software for Windows was used.

\section{RESULTS}

\section{Tree and epiphytic species characterization}

Aextoxicon punctatum was the main species tree inside the plot, while other species, such as N. obliqua, Eucryphia cordifolia Cav., L. philippiana and $P$. lingue, had a much more limited presence. Nothofagus obliqua is deciduous while $A$. punctatum has abundant and dense foliage, which lowers the brightness inside the forest. However, the lighting of the tree tops in most of these was full, belonging to the dominant canopy layer.

The rest of them corresponded to the emerging class these are trees that go beyond the dominant stratum and are noted for their height. $N$. obliqua, $E$. cordifolia and some individuals of $A$. punctatum and $L$. philipiana belong to this class

The type of shaft was a factor that could influence the colonization of epiphytic species). The species $A$. punctatum evaluated in two situations had a type called smooth bark, which has no large cracks or fissures, while $N$. obliqua had cracked and rough shaft.

The identified vascular epiphyte species were mainly ferns. It was possible to observe that Asplenium dareoides A.N. Desv., Hymenoglossum cruentum (Cav) Presl and Hymenophyllum cuneatum Kunze are the only species that are not common to the 3 assessed situations. With respect to coverage of epiphytic species, it is important to note that Hymenophyllum caudiculatum Mart and $H$. cuneatum species were recorded $75 \%$ above cover values. Sociability was an attribute of the epiphytic vegetation evaluated in field. 
By the way, A. dareoides was the only species with growth evaluated in the situations. Besides, the number of plants recorded for the same species was quite low, since plants mainly developed at the base of the shafts (San Martín et al., 2008; Zanetti, 2004). Unlike, H. cuneatum and $H$. caudiculatum were the only species that were found growing in almost pure populations.

\section{Soil and epiphytes substrate physicochemical properties}

A significant $(P \leq 0.05)$ average soil temperature was observed (Table 1) when comparing SS in different situations, reaching higher temperatures in the ES, whose values were among 14.8 and $16.8^{\circ}$
C (Table 1). However, when comparing ES in three evaluated situations no significant differences $(P>0.05)$ were observed. The moisture (Table 1) showed significant differences $(P \leq 0.05)$ various situations, obtaining higher moisture levels in BT situation with an average of $63.5 \%$ and $55 \%$ in ES and SS, respectively. Lower moisture levels were obtained in the MGBT situation, due to the presence of a gap in the forest. In relation to $\mathrm{OM}$ content, significant differences $(P \leq 0.05)$ in BT and MGBT situations were observed (Table 1).

The $\mathrm{P}$ availability showed significant differences $(P \leq 0.05)$ in the various assayed ecological situations, having a greater availability in the BT and DST situations, both in ES and SS.

Table 1. Physicochemical parameters in epiphytes substrate (ES) and surrounding soil forest land (SS) for three ecological situations in a temperate forest from south-central Chile.

\begin{tabular}{|c|c|c|c|c|c|c|c|}
\hline & \multicolumn{2}{|c|}{ BT Situation } & \multicolumn{2}{|c|}{ DST Situation } & \multicolumn{3}{|c|}{ MGBT Situation } \\
\hline & ES & SS & ES & SS & ES & SS & LSD \\
\hline Olsen $P\left(\mathrm{mg} \mathrm{kg}^{-1}\right)$ & 9.9 & 4.3 & 19.7 & 5.3 & 14.0 & 5.4 & n.s. \\
\hline Organic Matter (\%) & 48.1 & 27.9 & 24.0 & 25.0 & 36.0 & 31.0 & n.s. \\
\hline pH (water) & 6.1 & 5.3 & 5.9 & 5.1 & 6.6 & 5.3 & n.s. \\
\hline Soil Moisture (\%) & 55 & 38 & 63.5 & 40 & 23.5 & 46.0 & n.s. \\
\hline Temperature $\left({ }^{\circ} \mathrm{C}\right)$ & 14.8 & 12.1 & 14.8 & 13.9 & 16.8 & 15.1 & n.s. \\
\hline
\end{tabular}

BT, bifurcated trees; DST, dead standing trees; MGBT, medium gap border trees; n.s. not significant $(P \leq 0.05)$

\section{Microbial biomass and enzyme activities \\ Epiphytes substrate in BT showed the highest levels of FDA hydrolysis, MBC and MBN (Figure 2), the highest urease activity (Figure 3) and significant differences $(P \leq 0.05)$ in respect to SS. All results mentioned above are consistent with the high OM content, moisture and temperature (Table 1).}

Moreover, DST ecological situation showed no significant differences $(P>0.05)$ in FDA hydrolysis both ES and SS. In contrast, MGBT ecological situation presented significant differences $(P \leq 0.05)$ between $\mathrm{SS}$ and $\mathrm{ES}$, with high values in $\mathrm{SS}$.

The MBC content showed significant differences $(P \leq 0.05)$ in three evaluated ecological situations, being higher in ES (Figure 2b). The NBM showed significant 
differences $(P \leq 0.05)$ in $\mathrm{BT}$ and MGBT ecological situations (Figure 2c).

Acid phosphatase activity presented the highest levels in BT ecological situation (Figure 3a), probably to improve the low levels of available phosphorus (Table 2) with significant differences $(P \leq 0.05)$ between SS and ES.

Finally, urease activity also showed the highest level in BT ecological situation (Figure 3b), but in ES, with significant differences $(\mathrm{p} \leq 0.05)$ between both them.
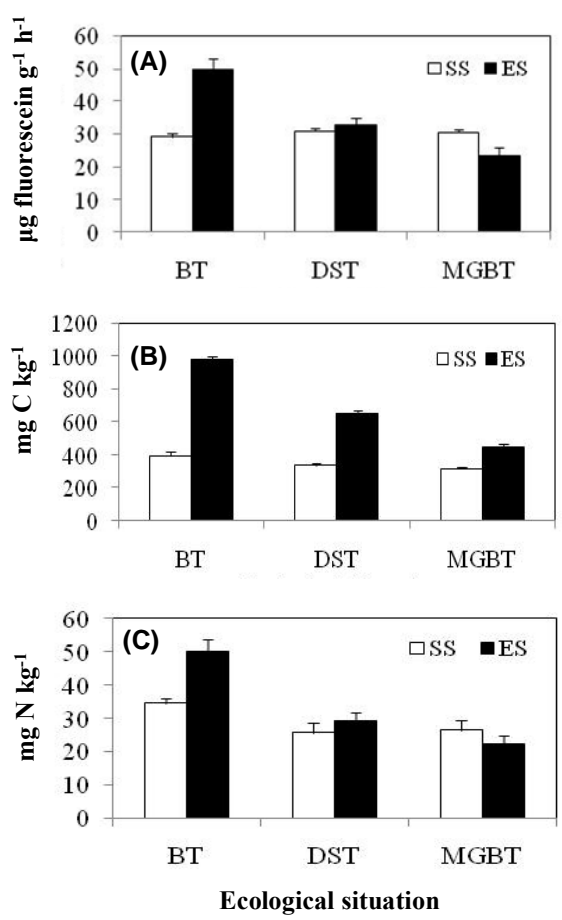

Figure 2. FDA hydrolysis (A), microbial biomass carbon (MBC) (B) and nitrogen $(\mathrm{MBN})(\mathbf{C})$ in epiphyte substrate (ES) and surrounding soil (SS) for three trees ecological situations in a temperate forest from south-central Chile. BT, bifurcated trees; DST, dead standing trees; MGBT, medium gap border.

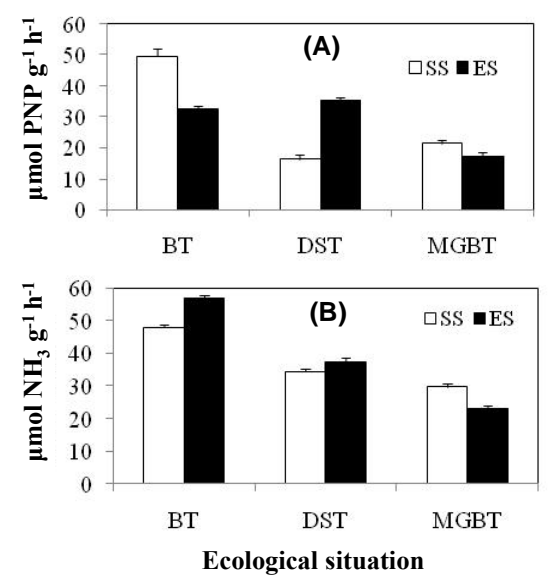

Figure 3. Hydrolytic enzyme activities in epiphyte substrate (ES) and surrounding soil (SS) for three ecological situations in a temperate forest from south-central Chile. BT, bifurcated trees; DST, dead standing trees; MGBT, medium gap border trees. Acid phosphatase (A) and urease (B) activities.

\section{Correlations between biological variables}

In general, close relationships were found among all evaluated biochemical variables (Table 2). They were significant $(\mathrm{r}=0.60, P \leq 0.01)$, which agrees well with results reported by Alvear et al. (2008)

\section{DISCUSSION}

The selection of host species or phorophytes is consistent with the tree species best described as hosts by Zanetti (2004) and San Martín et al. (2008), who suggest that $A$. punctatum and $N$. obliqua tree species have special characteristics in their shaft and foliage that favour the colonization of vascular epiphytes. Moreover, all these species of epiphytes 
Table 2. Correlations among biochemical properties and physicochemical in both epiphytes substrate (ES) and surrounding soil forest land (SS) for three ecological situations in a temperate forest from south-central Chile.

\begin{tabular}{|c|c|c|c|c|c|c|c|c|c|c|}
\hline & FDA & MBC & MBN & P-ase & Urease & pH & OM & Moist. & $\begin{array}{c}\text { Olsen } \\
\mathbf{P}\end{array}$ & Temp. \\
\hline FDA & 1 & $0.82(* *)$ & $0.86(* *)$ & n.s. & $0.78(* *)$ & n.s & n.s & n.s & n.s. & n.s. \\
\hline MBC & & 1 & $0.80(* *)$ & n.s. & $0.68(* *)$ & $0.67(* *)$ & n.s & n.s & n.s. & n.s. \\
\hline MBN & & & 1 & n.s. & $0.91(* *)$ & n.s. & n.s & n.s & n.s. & n.s. \\
\hline P-ase & & & & 1 & $0.68(* *)$ & n.s. & $0.75(* *)$ & $0.72(* *)$ & n.s. & n.s. \\
\hline Urease & & & & & 1 & n.s. & n.s & $0.96(* *)$ & n.s. & n.s. \\
\hline pH & & & & & & 1 & n.s & n.s. & n.s. & n.s. \\
\hline OM & & & & & & & 1 & n.s. & n.s. & n.s. \\
\hline Moist & & & & & & & & 1 & n.s. & n.s. \\
\hline Olsen P & & & & & & & & & 1 & n.s. \\
\hline Temp. & & & & & & & & & & 1 \\
\hline
\end{tabular}

**Pearson correlation with a significance level $99 \%(P \leq 0.01) . \mathrm{FDA}=$ fluorescein diacetate hydrolysis, $\mathrm{MBC}=$ microbial biomass carbon, $\mathrm{MBN}=$ microbial biomass nitrogen, $\mathrm{P}$-ase $=$ acid phosphatase, Moist. $=$ moisture, Temp. $=$ temperature .

recorded in the sampling are preferably A. punctatum. This may be because this tree species has denser and less translucent foliage, which reduces the light entering the forest, more specifically at its stem, which according to Godoy et al. (1981) favours growth of epiphytic ferns, with dominant composition in the region of temperate forest in Southern Chile (Godoy et al., 1989)

Thus, favoring higher rates of moisture and temperature, and hence the activity of soil biota, which was reflected in BT ecological situation (Figure 2a). Besides, ES was covered with litter of tree species and shrubs creating a microclimate which favored rapid degradation and incorporation of plant material. This was deposited on the bifurcation, which increased the microorganism growth and enzyme secretion. We agree with Nadkarni et al. (2004), on to activity levels of active biota, they are dependent on the quantity and quality of compounds from OM degradation, we can not foresee that the degradation rate is maintained for a period of time, even if there was a mossy covered on the substrate, with abundant species of mosses and lichens, mainly those that were not fixed to the substrate. In addition, agreeing with Rousk and Nadkarni (2009), a possible explanation for the differences between $\mathrm{SS}$ and $\mathrm{ES}$ in BT ecological situation is related to OM content (Table 1).

The high MBC content in ES is due primarily to the increased incorporation of carbon compounds, proceeding from fungi. The organism ability to retain and immobilize them for later use as energy source; regarding the content of $\mathrm{MBN}$, Flores-Palacios and García-Franco (2004), have indicated that the decomposition of biomass from vascular and non-vascular epiphytes is rich in nitrogen. It is consistent with the low $\mathrm{C} / \mathrm{N}$ biomass, increasing $\mathrm{N}$ input to the $\mathrm{ES}$ community and microorganisms, favoring the nutrient availability for their growth.

On the SS, there was a greater accumulation of plant material, but with a lower degradation rate, given a high $\mathrm{C} / \mathrm{N}$ ratio soil biomass. It reduced energy sources for microorganisms, not with respect to acid phosphatase activity, which was significantly higher $(P \leq 0.05)$ (Figure 3a). This situation reflects a low number and/or quality of phosphate 
substrates, but ES is not observed. Furthermore, low $\mathrm{P}$ availability in SS stimulated the secretion of phosphatase by its own microorganisms and plant roots, which was helped by the extensive $A$. punctatum root system.

Inselsbacher et al. (2007), suggested that epiphytes can be efficient in the hydrolysis of urea to $\mathrm{NH}_{4}{ }^{+}$, urea excretion from insects that live along both the shaft and within the substrate; if urea content is rapidly hydrolyzed by the microorganisms when secreting urease, before the $\mathrm{NH}_{4}{ }^{+}$ ion, it can be assimilated by plants, which account for their microbial origin. In our study the urease activity was highly significant $(P \leq 0.05)$ in ES.

The vegetation cover in ES in the DST ecological situation is formed by Hymenophyllum species, especially Hymenophyllum plicatum Kaulf., some mosses and lichens. Epiphytic species belonging to the Hymenophyllaceae family are described as having a rhizome, so each plant is connected to other of their species for long stretches, even to the base of the tree shaft (Marticorena and Rodríguez, 1995). This situation favors the regeneration of species in the understory and interradicular tree space being no significant differences $(P>0.05)$ in the hydrolysis of FDA between the ES and $\mathrm{SS}$, even when the $\mathrm{pH}$ condition, moisture and temperature were more favorable in the ES (Figure 2a). Furthermore, the accumulation of litter is mainly supplied from the $N$. obliqua, E. cordifolia and A. punctatum species. This accumulation of litter stimulated the proliferation and biota activity, generating an increase in OM degradation rate reaching a level similar to the substrate, with a consequent release of carbon compounds and nitrogen for microorganisms, increasing their activity themselves. The high MBN content indicates that the decomposition of lichen litter was lower than the decomposition of plant material accumulated on the forest soil, with a slow $\mathrm{N}$ release which led to a rapid immobilization of nutrients by microorganisms, while the $\mathrm{P}$ release seems to be faster. Moreover, it demonstrates a greater proliferation of bacterial biomass of ES due to $\mathrm{pH}$ condition (Table 1).

Acid phosphatase was significantly higher in ES (Figure 3a, $P \leq 0.05$ ) due to the non-excretion of organic acids and phosphorus compounds from the roots of A. punctatum forest trees. This is caused by differences in chemical plant material composition produced in each environment (data not shown) accumulated on the soil mostly leaves, branches, twigs and shaft residues, while in ES with no vascular plant material this quickly joined it. Urease activity showed no significant differences (Figure 3b, $P>0.05)$, indicating that the contribution of nitrogen compounds in two environments was similar, varying the reserve of this element by microorganisms.

The colonization of epiphytes in MGBT situation, preferably for the species accounted for Hymenophyllum secundum Hook. Grev., which demonstrated a high degree of desiccation, a sign of low humidity and substrate moisture. At the same time, Benzing (1989) notes that Hymenophyllaceae have a high resistance to desiccation, being able to survive for short periods, applying their strategy of rolling and then returning to normal condition. This affected the activity levels of active biota (FDA hydrolysis), which were significantly lower $(P \leq 0.05)$ in ES.

The presence of a gap had a direct bearing on the shaft and so low moisture in ES and a lower OM accumulation and content was produced, limiting the release and transport of nutrients to and from microorganisms. Linking the proliferation and activity of microorganisms in the 
ecological condition, Arunachalam and Arunachalam, (2000) indicate that there would be a strong correlation between the gap and the prevalence of bacterial biomass in both ES and SS since an increasing community of denitrifying bacteria is produced at higher $\mathrm{pH}$ values (Table 1). However, MBN levels do not reflect this condition (Figure 2c). Meanwhile, the MBC revealed no significant differences $(P>0.05)$ due to low plant material supply and/or substrate instability. The ecological strategy of rolling of Hymenophyllaceae epiphytes can act as insulation against of temperature and moisture fluctuations inside the substrate avoiding greater carbon losses, solubilizing some carbonaceous components, but it is not enough to increase levels of microbial content to levels that differentiate them from the soil. However, they provide and/or maintain a similar environment to the soil. Enzyme activities (Figure $3 \mathrm{a}$ and $3 \mathrm{~b})$ were significantly higher $(P \leq 0.05)$ in $\mathrm{SS}$, favored by the highest OM content, accumulation and degradation and a more favorable condition of moisture and temperature. It is possible that different $\mathrm{P}$ levels in each environment make a difference in the potential for acid phosphatase production by microorganisms, thus, a low $\mathrm{P}$ availability stimulates the secretion of the enzyme. Similarly, the secretion of urease derived from microorganisms actively transforms nitrogen compounds from the OM deposited on the substrate and from the bacterial biomass that grows on the leaves of epiphytes, when $\mathrm{pH}$ and moisture conditions favor the proliferation of this type of microorganisms, it can fix significant nitrogen amounts.

\section{Correlations}

FDA hydrolysis and MBN properties showed very similar behavior in assessed situations, which is confirmed by the high correlation obtained (Table 2) finding the highest levels of microbial population in BT and DST both ES and SS. Unlike MGBT, the gap effect on ES, had lower rates in both parameters due to lower moisture levels, as the MBN is controlled by soil moisture content (Hart and Firestone , 1991) $(\mathrm{r}=0.88, P \leq 0.01)$. In the case of $\mathrm{MBC}$, it had a similar interaction with the above mentioned, with high levels of correlation with the FDA and MBN ( $r=0.82$ and $r=0.80$, respectively), although the $\mathrm{MBC}$ levels were always higher in epiphytic in three ecological situations. This suggests that FDA hydrolysis may be related to fungal biomass, according to Gaspar et al. (2001) and Anderson and Domsh (1980), since higher moisture levels and more acid $\mathrm{pH}$ tend to proliferate these kinds of microorganisms $(r=0.63, P \leq 0.01$ and $r=$ $0.67, P \leq 0.01$, respectively).

Acid phosphatase activity was positively correlated to moisture and OM. The composition of epiphytic species that colonized the shafts affected the quality and solubility of phosphate compounds that derived from the OM degradation $(\mathrm{r}=$ $0.75, P \leq 0.01, \mathrm{r}=0.72, P \leq 0.01$, values for $\mathrm{OM}$ and moisture, respectively). Urease activity presented correlation with FDA hydrolysis, $\mathrm{MBC}, \mathrm{MBN}$, moisture and acid phosphatase activity. This situation appears to be related to the microbial origin of the enzyme and the type of substrate, suggesting that urease is affected by the nature of the vegetation cover (Bastida et al., 2006; Steubing et al., 2002)

\section{CONCLUSIONS}

Our study demonstrated that each situation presents a different microclimate for vascular epiphytes development, 
although the samples points were located at short distance one from another. The microorganisms as evaluated enzymes in epiphytic substrate activity varied in each situation. This indicates a clear dependence according to moisture and temperature conditions, $\mathrm{pH}, \mathrm{OM}$ content and $\mathrm{P}$ availability. In turn, shaft exudates and substrate characteristics formed by litter deposit and vegetal OM residues and non vascular epiphytes layer seemed to influence the vascular distribution.

The research performances with the purpose of studying the nutrients dynamics allow complementing and broadening the areas of study starting from the enzyme activities and secretion from microorganisms and their interaction with the substrate of a various epiphyte communities. This type of study helps to clarify in a deeper way the nutrients dynamics and vascular epiphytes community composition under the different environmental conditions of temperate forests starting from highly sensitive biological indicators.

\section{ACKNOWLEDGMENTS}

This work was supported by both DIUFRO EP Projects $\mathrm{N}^{\circ} 120316$ and $\mathrm{N}^{\circ}$ 120501. We thank Mrs. María Eugenia Osses for her valuable comments and help in redaction the manuscript in english.

\section{REFERENCES}

Alvear, M., Astorga, M., Reyes, F. 2008 Efecto de los residuos vegetales provenientes de dos tratamientos silvícolas en una plantación de Pinus radiata D. Don sobre los cambios estacionales de las actividades biológicas del suelo. Journal of Soil Science and Plant Nutrition 8(1):14-27

Alvear, M., Reyes, F., Morales, A., Arriagada, C., Reyes, M. 2007. Actividad biológica y agregados estables al agua en dos tipos de formaciones vegetales de un bosque templado del Centro-Sur de Chile con perturbación antrópica. Ecología Austral. 17:113-122.

Anderson, I.P., Domsch, K.H. 1980. Quantities of plant nutrients on the microbial biomass of selected soils. Soil Science. 130: 211-216.

Antibus, R.K., Lesica, P. 1990. Root surface acid phosphatase activities of vascular epiphytes of a Costa Rica rain forest. Plant and Soil. 128: 233-240.

Armesto, J.J., Rozzi, R., Smith-Ramírez, C., Arroyo, M.T.K. 1998. Conservation targets in South American temperate forests. Science, 282: 1271-1272.

Arunachalam, K., Arunachalam, A. 2000. Influence of gap size and soil properties on microbial biomass in a subtropical humid forest of north-east India. Plant and Soil. 223 : 187-195.

Bastida, F., Barberá, G.G., García, C., Hernández, T. 2006. Influence of orientation, vegetation and season on soil microbial and biochemical characteristics under semiarid conditions. Applied and Soil Ecology. 38: 6270 .

Benzing, D.H. 1989. The Evolution of epiphytism. In Vascular plants as epiphytes: evolution and ecophysiology. Edited by U. Lüttge. Ecological Studies, Vol. 76. Springer Verlag. Berlin Heidelberg, Germany. 270 pp.

Brookes, P.C., Landman, A., Pruden, G., Jenkinson, D.S. 1985. Chloroform fumigation and the release of soil nitrogen: a rapid direct extraction method to measure microbial biomass nitrogen in soil. Soil Biology and Biochemistry. $17,837-842$.

Cardelús, C. L., Colwell, K. R., Watkins Jr., J. E. 2006. Vascular epiphyte distribution patterns: explaining the mid-elevation richness peak. Journal of Ecology. 94: 144-156.

Donoso, C. 1992. Ecología Forestal, el bosque y su medioambiente. Tercera edición. Editorial Universitaria. Santiago, Chile. 369 pp.

Flores-Palacios, A., García-Franco, J.G. 2004. Effect of isolation on the structure and nutrient content of oak epiphyte communities. Plant and Ecology. 173: 259-269.

Galantini, J.A., Suñer, L. 2008. Las fracciones orgánicas del suelo: análisis en los suelos de la Argentina. Agriscientia, 25: 41-55. 
Gaspar, M., Cabello, M.N., Pollero, R., Aon, M.A. 2001. Fluorescein diacetate hydrolysis as a measure of fungal biomass in soil. Current of Microbiology 42: 339-344.

Gil-Sotres, F., Trasar-Cepeda, C., Ciardi, C., Ceccanti, B. 1992. Biochemical characterization of biological activity in very young mine soils. Biology and Fertility of Soils. 13: 25-30.

Godoy, R., Oyarzún, C., Gerding, V. 2001. Precipitation chemistry in deciduous and evergreen Nothofagus forests of southern Chile under low-deposition climate. Basic and Applied Ecology. 2: 65-72.

Godoy, R., Figueroa, H. 1989. Composition and distribution of the Pteridophyte flora of continental and insular Chile. Nova Hedwigia. 48: 437-453.

Godoy, R., Ramírez, C., Figueroa, H., Hauenstein, E. 1981. Estudios ecosociológicos en pteridófitos de comunidades boscosas Valdivianas, Chile. Bosque. 4: 12-24.

Granados, D., Tapia, R. 1990. Comunidades vegetales. Castillejos, S. y Rodríguez, J. Editores. Colección Cuadernos Universitarios. Serie Agronomía $\mathrm{N}^{\circ}$ 19. Universidad Autónoma de Chapingo. México. 235 pp.

Gullison, R.E., Nissan, S. 1999. Evaluación de la factibilidad del modelado de los impactos del manejo forestal sobre la biodiversidad en la concesión de Tarumá. Doc. Técnico 77. Proyecto Forestal Sostenible Bolivia BOLFOR. Editorial Cuarto Anillo. Santa Cruz, Bolivia. 108 pp.

Hart, S.C., Firestone, M.K. 1991. Forest floormineral soil interactions in the internal nitrogen cycle of an old-growth forest. Biogeochemistry. 12: 103-127.

Hernández-Rosas, J. 2001. Ocupación de los portadores por epífitas vasculares en un bosque húmedo tropical del Alto Orinoco, Edo. Amazonas, Venezuela. Acta científica Venezolana. 52: 292-303.

Higuera, D., Martínez, E. 2006. Litterfall and nutrient fluxes in canopy oaks in neotropical cloud forest, Colombia. Lyonia.11: 67-74.

Huygens, D., Denef, K., Vandeweyer, R., Godoy, R., Van Cleemput，O., Boeckx, P. 2008. Do nitrogen isotope patterns reflect microbial colonization of soil organic matter fractions?. Biology and Fertility of Soils. 44: 955-964.
Inselsbacher, E., Aguetoni, C., Richter, A., Florian, C., Mercier, H., Wanek W. 2007. Microbial activities and foliar uptake of nitrogen in the epiphytic bromeliad Vriesea gigantea. New Phytologist. 175: 311- 320.

Joergensen, R., Brookes, P. 1990. Ninhydrinreactive measurements of microbial biomass in $0.5 \mathrm{M} \mathrm{K}_{2} \mathrm{SO}_{4}$ soil extracts. Soil Biology and Biochemistry. 22: 1023-1028.

Joergensen, R. 1996. Quantification of microbial biomass by determining ninhydrinreactive N. Soil Biology and Biochemistry. 28: 301-306.

Kimmins, J. P. 1996. Forest ecology: a foundation for sustainable management. Second edition. Prentice Hall Inc. New Jersey. United States. 596pp.

Margalef, R. 1998. Ecología. Novena Edición (Reimpresión). Ediciones Omega. Barcelona, España. 951 pp.

Marticorena, C., Rodríguez, R. (Editores). 1995. Flora de Chile. Volumen I: Pteridophyta Gymnospermae. Universidad de Concepción. Concepción, Chile. 351 pp.

Nadkarni, N.M., Schaefers, D., Matelson, T.J., Solano, R. 2004. Biomass and nutrient pools of canopy and terrestrial components in a primary and a secondary montane cloud forest, Costa Rica. Forest Ecology and Management. 198: 223-236.

Olson, D., Dinerstein, E. Wikramanayake, E. Burgess, E., Powell, G., Underwood, E. D'amico, J., Itoua, I., Strand, H., Morrison, J., Loukes, C., Allnutt, T., Ricketts, T., Kura, Y., Lamoreux, J., Wettengel, W., Hedao, P., Kassem, K. 2001. Terrestrial ecoregions of the world: A new map of life on earth. Bioscience. 51: 933-938

Pérez, C.A., Guevara, R., Carmona, M.R., Armesto, J.J. 2005. Nitrogen mineralization in epiphytic soils of an old-growth Fitzroya cupressoides forest, southern Chile, Ecoscience. 12: $210-215$.

Rousk, J., Nadkarni, N. 2009. Growth measurements of saprotrophic fungi and bacteria reveal differences between canopy and forest floor soils. Soil Biology and Biochemistry. 41: 62-65. 
San Martín, J., Espinosa, A., Zanetti, S. Hauenstein, E., Ojeda, N., Arriagada, C. 2008. Composición y estructura de la vegetación epífita vascular en un bosque primario de Olivillo (Aextoxicon punctatum R. et P.) en el sur de Chile. Ecología Austral. 18: 1-11.

Schlegel, B.C., Donoso, P.J., 2008. Effects of forest type and stand structure on coarse woody debris in old-growth rainforests in the Valdivian Andes, south-central Chile. Forest Ecology and Management. 255: 1906-1914.

Smith, R.L., Smith, T.M. 2001. Ecología. Cuarta edición. Pearson Education S.A., Madrid. 664 pp.

Steubing, L., Godoy, R., Alberdi, M. 2002. Métodos de Ecología Vegetal. Primera edición. Editorial Universitaria. $345 \mathrm{pp}$.

Vance, F., Brookes, P., Jenkinson, D. 1987. Microbial biomass measurements in forest soils: The use of the chloroform fumigation-incubation method in strongly acid soils. Soil Biology and Biochemistry. 19: 697-702.

Vance, E., Nadkarni N.M. 1990. Microbial biomass and activity in canopy organic matter and the forest floor of a tropical cloud forest. Soil Biology and Biochemistry. 22: 677-84.
Vann D. R., Joshi, A., Pérez, C., Johnson, A.H., Frizano, J. Zarin, D.J., Armesto, J.J. 2002. Distribution and cycling of $\mathrm{C}, \mathrm{N}, \mathrm{Ca}, \mathrm{Mg}$, $\mathrm{K}$ and $\mathrm{P}$ in three pristine, old-growth forests in the Cordillera de Piuchué, Chile. Biogeochemistry 60:25-47.

Zagal, E., Rodríguez, N., Vidal, I., Quezada, L. 2002. Actividad Microbiana en un Suelo de Origen Volcánico Bajo Distinto Manejo Agronómico. Agricultura Técnica. 62: 297-309.

Zanetti, S. 2004. Estudio de la vegetación epífita vascular en un bosque adulto de olivillo. (Temuco, Chile). Tesis Ingeniero Forestal. Universidad de La Frontera. Temuco, Chile. 83 pp.

Zúñiga, A., Muñoz-Pedreros, A., Fierro, A. 2008. Dieta de Lycalopex griseus (Gray, 1837) (mammalia: canidae) en la depresión intermedia del sur de Chile. Gayana Botanica. 72: 113-116. 